\author{
MILITARY TECHNICAL COLLEGE \\ CAIRO - EGYPT
}

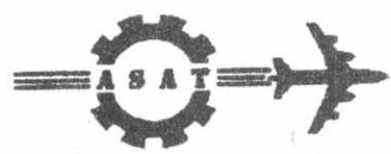

$7^{\text {th }}$ INTERNATIONAL CONF. ON AEROSPACE SCIENCES \& AVIATION.TECHNOLOGY

\title{
MULTI-METAL OXIDE AEROGEL FOR CAPTURE OF POLLUTION GASES FROM AIR
}

\author{
M. S. Ahmed* and Y. A. Attia**
}

\begin{abstract}
Utilization of fossil fuels results in the emission of pollution gases such as $\mathrm{CO}_{2}, \mathrm{SO}_{2}, \mathrm{CO}$, $\mathrm{NO}_{x}$ and $\mathrm{H}_{2} \mathrm{~S}$. Currently available commercial technologies for reducing $\mathrm{SO}_{2}$ and $\mathrm{NO}_{\mathbf{x}}$ emissions from power plants are costly and produce hazardous wastes. The concept described in this paper uses advanced aerogel materials containing components such as $\mathrm{CaO}$ and $\mathrm{MgO}$ in their structure to capture/adsorb gaseous wastes from fossil fuel combustion. Aerogels are typically highly porous materials, which can have over $90 \%$ porosity, very low density, and extremely high surface area (several hundred $\mathrm{m}^{2} / \mathrm{g}$ ). The test results of this work indicated that an aerogel sorbent containing $\mathrm{CaO}, \mathrm{MgO}$ and $\mathrm{SiO}_{2}$, which is prepared in the laboratory "by the advanced sol-gel technology", can be used efficiently to capture/adsorb pollution gases such as $\mathrm{CO}_{2}, \mathrm{SO}_{2}, \mathrm{NO}_{\mathrm{x}}, \mathrm{CO}$ and $\mathrm{H}_{2} \mathrm{~S}$ through both physical and chemical sorption mechanisms. Aerogels can be engineered to different forms, sizes, and chemical compositions to be used as gas filters in the different workplaces and indoor living spaces.
\end{abstract}

\section{KEY WORDS}

Aerogel materials, Sol-gel process, Fuels, Pollution gases, Gas adsorption.

* Associate professor. Suez Camal Iniversity, Dept. Of Metallurgical Engineering,

Faculty of Petroleum and Mining Engineering, Suez, Egypt.

** Professor, TAASI Laboratory, Columbus, OH, U.S.A. 


\section{INTRODUCTION}

Utilization of fossil fuels (coal, oil and gas) in stationary (e.g., diesel generators, electric power, metallic, cement, ceramic, chemical, and other plants) and mobile (e.g., diesel trucks, buses, automobiles, air planes, etc.) results in the emission of gases such as $\mathrm{CO}_{2}, \mathrm{CO}, \mathrm{SO}_{2}$, and $\mathrm{NO}_{\mathbf{x}}$ (greenhouse gases) into the atmosphere, in addition to $\mathrm{H}_{2} \mathrm{~S}$ which is mainly produced from the petrochemical industries. These gases are blamed for environmental problems such as acid rain, global warming, ozone depletion, corrosion, and increased toxicity of breathing air.

The currently available commercial technology for reducing $\mathrm{SO}_{2}$ and $\mathrm{NO}_{\mathrm{x}}$ emission from power plants is wet scrubbing. However, since this technology is costly and creates hazardous slurry wastes, it has not found wide acceptance from power utilities and the various manufacturing plants. Further, wet scrubbing is not suitable for mobile applications. Dry sorbent injection technologies seem to be more promising, however, they also produce dry hazardous wastes. In a power plant, the dry sorbents are injected either in the combustion furnace $\left(1204^{\circ} \mathrm{C}\right)$, the economizer zone $\left(538^{\circ} \mathrm{C}\right)$, or the "cool side" ducts $\left(70^{\circ} \mathrm{C}\right)$, [1]. Typical sorbents include finely ground limestone, dolomite, hydrated lime, sodium bicarbonate and sodium sesquicarbonate. The sorbents react with $\mathrm{SO}_{2}$ emissions to form solid products such as $\mathrm{CaSO}_{4}$ or $\mathrm{Na}_{2} \mathrm{SO}_{4}$, which are then removed with the coal ash or with the dust by the particulate collection system (e.g., electrostatic precipitator or baghouse), depending on the point of injection. Of these approaches, limestone injection is considered to be commercially proven. Typical removal levels of $\mathrm{SO}_{2}$ by calcium and magnesium sorbents at $\mathrm{Ca} / \mathrm{S}$ ratio $=2$ are: limestone; $25-40 \%$, dolomite; $40-60 \%$, and hydrated dolomite; $60-80 \%$, [1].

As mentioned earlier, $\mathrm{SO}_{2}$ can be removed from the flue gases by adding calcium-based sorbent according to the following chemical reaction :

$$
\mathrm{CaO}+\mathrm{SO}_{2}+0.5 \mathrm{O}_{2}=\mathrm{CaSO}_{4}
$$

Electron microscope examination, [2], showed that this reaction takes place only within a thin layer on the outer surface of the sorbent particles. Thus, the finer the particle the higher the utilization rate of the sorbent. However, finer particles are more easily carried out of the bed by the flue gas; as a consequence, their reaction time is shortened leading to incomplete reaction and inefficient utilization of the sorbent. To solve this problem a method of agglomerating fine limestone particles with some adhesive substances, has been developed and used in China, [2,3]. This is called synthetic Ca-based sulfur sorbent with high reactivity.

For natural limestone, reactant gases $\left(\mathrm{SO}_{2}\right.$ and $\left.\mathrm{O}_{2}\right)$ diffuse into the inside particles only through the small pores and react with $\mathrm{CaO}$ grains to produce solid $\mathrm{CaSO}_{4}$ which then covers the surface of $\mathrm{CaO}$ grains. In a short time, these small pores are filled, which limits the diffusion of reactant gases into the particles. So the overall $\mathrm{CaO}$ conversion rate of natural limestone particles is very low. However, with synthetic sorbents which are prepared by agglomerating small particles of limestone with a binder, reactant gases not only directly diffuse into grain groups near the surface, but also directly penetrate to internal groups through the large pores between the grain groups. This is beneficial for increasing the overall $\mathrm{CaO}$ conversion rate. 
Activated carbon (coke) has been used in Germany, [4], to adsorb $\mathrm{SO}_{2}$ from the hot gases in the presence of $\mathrm{O}_{2}$ and $\mathrm{H}_{2} \mathrm{O}$ vapor according to the following reaction:

$$
2 \mathrm{SO}_{2}+\mathrm{O}_{2}+2 \mathrm{H}_{2} \mathrm{O}_{(\mathrm{g})}=2 \mathrm{H}_{2} \mathrm{SO}_{4}
$$

Sulfuric acid $\left(\mathrm{H}_{2} \mathrm{SO}_{4}\right)$ is later desorbed (released) from the activated carbon by heating with hot sand according to the following reaction:

$$
2 \mathrm{H}_{2} \mathrm{SO}_{4}+\mathrm{C}=2 \mathrm{H}_{2} \mathrm{O}+\mathrm{CO}_{2}+2 \mathrm{SO}_{2}
$$

The degree of desulfurization achieved by this method has not been reported. Activated carbon is expected to capture gases by physical adsorption mechanism as there are no chemisorption mechanisms available.

Because of the obvious benefits of having porous agglomerates of the calcium based sorbents, or porous activated carbon, in increasing the efficiency of $\mathrm{SO}_{2}$ capture and reactivity, [1-5], we believe that aerogel materials containing $\mathrm{CaO}$ and/or other metallic oxides in their structure, will be much more efficient sorbents than calcium based powders, agglomerates, or activated carbon, due to the aerogel's extremely high porosity, high surface area, and the incorporated metallic oxides. Also, aerogels can be molded to any shape and size, and thus are more flexible than the powder or agglomerate.

\section{Development of Aerogel Sorbents:}

Aerogel sorbent materials are made by the sol-gel process, shown schematically in Fig. $\mathrm{t}$, in which an alcoholic solution of a metal alkoxide e.g., magnesium ethoxide, $\mathrm{Mg}\left(\mathrm{OC}_{2} \mathrm{H}_{3}\right)_{2}$, or of a mixture of metal alkoxides and salts (e.g., nitrates), is hydrolyzed to form a sol (a colloidal suspension of the metal hydroxide, e.g., $\mathrm{Mg}(\mathrm{OH})_{2}$ in alcohol). A catalyst is then added to start the condensation polymerization process to form a gel (a continuous solid skeleton of the polymerized hydrolyzed material enclosing a continuous phase of the liquid alcohol). The aerogel is formed by removing the alcohol from the pores of the gel by supercritical drying in an autoclave, which minimizes shrinkage and cracking. The volume of the resulting aerogel is similar to that of the original sol, which makes the production of highly porous materials possible.

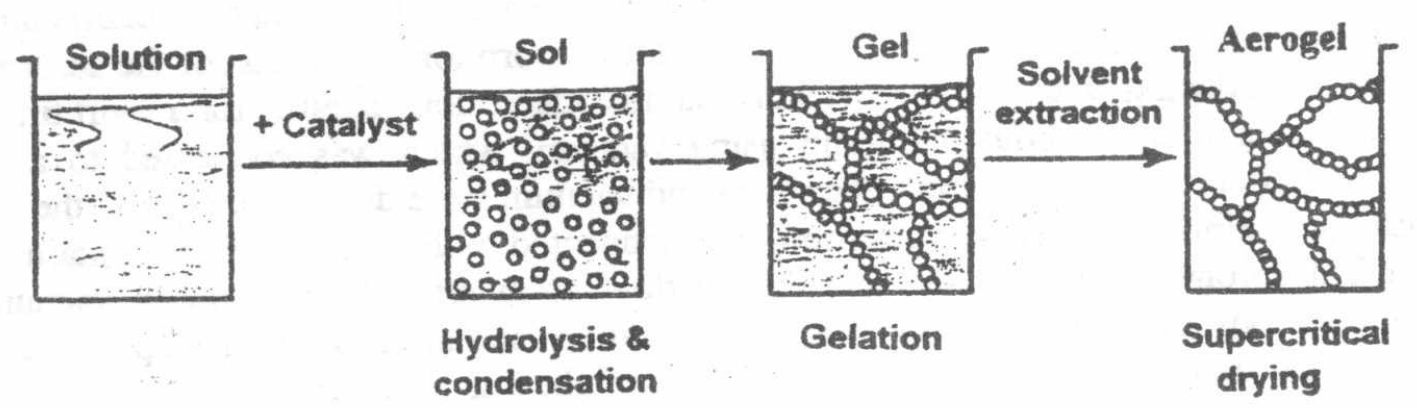

Fig. 1. Schematic diagram of the preparation of aerogel by sol-gel processing and supercritical drying for solvent extraction. 
Several investigators, [6,7], have developed and discussed the production of aerogel materials. Optimization of the various parameters involved was achieved, and improvements of the process were developed. The method was also extended from pure silica to various multi-systems. The very large surface area characterizing these materials, currently of several hundred $\mathrm{m}^{2} / \mathrm{g}$ (a pore diameter distribution extending from the $\mathrm{nm}$ to the $\mu \mathrm{m}$ range) made them attractive for several applications, e.g., the field of catalysis and thermal insulation,
$[6,7]$.

The main objective of this work was to investigate the feasibility of using an aerogel sorbent which is prepared in the laboratory, to adsorb/capture waste gases such as: $\mathrm{SO}_{2}, \mathrm{NO}_{\mathrm{x}}, \mathrm{CO}_{2}$,
$\mathrm{CO}$ and $\mathrm{H}_{2} \mathrm{~S}$

\section{EXPERIMENTAL PROCEDURES}

\section{(1) The Aerogel Sorbent:}

The tested aerogel, containing $\mathrm{CaO}, \mathrm{MgO}$ and $\mathrm{SiO}_{2}$, was manufactured through the preparation of the corresponding alcogel by the sol-gel processing technology, and then by subjecting the alcogel to supercritical drying in an autoclave to remove the alcohol. The produced aerogel specimens were then heat treated in air at 650-700 $\mathrm{C}$ to eliminate the organic residues after autoclave drying. The chemical and physical compositions of the prepared aerogel were adjusted through the molar ratio of the main components, type of precursors (chemical feed stock), catalyst type and concentration, and method of preparation. Figure 2 shows a flowchart of the procedure and precursors used.

\section{(2) Gas Adsorption Testing:}

Gas adsorption was measured by passing the test gas mixture with air over the aerogel sample enclosed in a stainless steel pressure filter vessel (adsorption chamber) and recording the change in gas concentration before and after the adsorption chamber as an indication of the extent of gas adsorption. It was found that the presence of water vapor (steam) enhances the gas adsorption of the process, [8]. Thus before adsorption, activation of the aerogel was made by introducing water vapor (steam) into the adsorption chamber for a short time (3-5 seconds) at a rate of about $0.7 \mathrm{~J} / \mathrm{min}$ using vacuum, which was connected to a steam generator. After the selected time, the steam and vacuum were disconnected, and the air-gas mixture (containing the gas in question) was connected to the pressure filter containing the humidified aerogel. The gas was allowed to flow at about $0.7 \mathrm{~V}$ min under vacuum, for selected periods of time. Prior to the humidification and gas adsorption steps, the aerogel sample was evacuated for a period of time and its weight was recorded.

To simulate flue gas system from high sulfur coal combustion, gases of $\mathrm{SO}_{2}, \mathrm{CO}_{2}$ and air were premixed to a desired composition range, i.e., about $1000-2500 \mathrm{ppm} \mathrm{SO}_{2}$ and $6-15.5 \%$ (vol.) $\mathrm{CO}_{2}$, by adjusting the valves of $\mathrm{SO}_{2}$ and $\mathrm{CO}_{2}$ cylinders directly so that the output of 
$\mathrm{SO}_{2}$ and $\mathrm{CO}_{2}$ from the cylinders were controlled. The pressures of these gases from the cylinders were only slightly above the atmospheric pressure (about $3 \mathrm{psi}$ ). Air was introduced directly from the atmosphere. NO gas was introduced in this simulation, but was tested in mixtures with air separately. $\mathrm{CO}$ and $\mathrm{H}_{2} \mathrm{~S}$ were each tested in mixtures with air also. At the beginning of each gas adsorption test, the concentration of each gas in the air mixture was tested by Drager Gas Detector Tubes supplied by SKC Inc., PA, U.S.A. The concentration of each gas coming out of the adsorption chamber was measured at different times also using the Drager gas analysis detector tubes. The inlet concentrations of each gas in the mixed gas stream before adsorption were again determined at the end of the test, (i.e., without passing through the aerogel filter first), to ensure that there was no change in the gas composition with time. Figure 3 is a schematic representation of the experiment setup. Approximately 1013 grams aerogel granules (grain size $<5 \mathrm{~mm}$ ) were tested in each experiment, although monolithic aerogel could also be used.

\section{RESULTS AND DISCUSSION}

The primary objective of this research program was to ascertain whether $\mathrm{CaO}$ and $\mathrm{MgO}$ containing aerogels can adsorb the greenhouse gases from air, specifically, $\mathrm{SO}_{2}, \mathrm{NO}, \mathrm{CO}_{2}$, $\mathrm{CO}$ and $\mathrm{H}_{2} \mathrm{~S}$ gases. Such adsorption has not been reported before. Once this has been ascertained, then research will continue to refine the aerogel preparation and gas adsorption processes to maximize the capacity of the aerogel to capture these gases.

Both small $(200 \mathrm{ml})$ and large $(1500 \mathrm{ml})$ monolith and granulated aerogel specimens (grain size $<5 \mathrm{~mm}$ ), containing oxides of $\mathrm{Ca}, \mathrm{Mg}$ and $\mathrm{Si}$, were prepared. Its density is approximately $0.12 \mathrm{~g} / \mathrm{cm}^{3}$, porosity is greater than $90 \%$ (estimated at about $96 \%$ ), color is white, and appearance is opaque.

Adsorption of single gases $\mathrm{SO}_{2}$ and $\mathrm{CO}_{2}$ by the prepared aerogel has been ascertained by $\mathrm{X}$ ray diffraction (XRD), and was reported earlier (Fig. 4), [8]. XRD spectrograms for the aerogel tested before and after adsorption of $\mathrm{SO}_{2}$ and $\mathrm{CO}_{2}$ show the existence of $\mathrm{MeSO}_{3}$ and $\mathrm{MeCO}_{3}(\mathrm{Me}$ refers to $\mathrm{Ca}$ and $\mathrm{Mg}$ ) in adsorption-tested aerogel specimens, which proves that this aerogel can adsorb these gases effectively. The adsorption test results also showed that the gas adsorption rate can be significantly increased by introduction of water vapor (steam). The role of the steam was considered to activate the gel surface by forming surface hydroxyl groups and therefore enhances the kinetics of chemisorption reactions on the gel surface according to the following equations:

$$
\begin{array}{ll}
\mathrm{CaO}+\mathrm{H}_{2} \mathrm{O} & =\mathrm{Ca}(\mathrm{OH})_{2} \\
\mathrm{Ca}(\mathrm{OH})_{2}+\mathrm{SO}_{2} & =\mathrm{CaSO}_{3}+\mathrm{H}_{2} \mathrm{O} \\
\mathrm{Ca}(\mathrm{OH})_{2}+\mathrm{CO}_{2} & =\mathrm{CaCO}_{3}+\mathrm{H}_{2} \mathrm{O}
\end{array}
$$

The possible chemisorption mechanisms for the gases considered in this investigation by $\mathrm{CaO}$ and $\mathrm{MgO}$ containing aerogels are listed in Table 1. 


\section{Adsorption of Gas Pollutants from Air :}

Adsorption of mixed $\mathrm{SO}_{2}$ and $\mathrm{CO}_{2}$ from simulated flue gas stream by the tested aerogel is shown in Fig. 5. It can be seen that $\mathrm{SO}_{2}$ and $\mathrm{CO}_{2}$ gases are adsorbed readily by the aerogel sorbent. Adsorption of $\mathrm{SO}_{2}$ ranged from $95 \%$ to nearly $100 \%$, while adsorption of $\mathrm{CO}_{2}$ ranged from $85 \%$ to about $100 \%$. The high concentration of $\mathrm{CO}_{2}(12.5 \%$ vol.) did not retard the adsorption of $\mathrm{SO}_{2}$ in the simulated flue gas mixture.

Adsorption of $\mathrm{NO}, \mathrm{CO}$ and $\mathrm{H}_{2} \mathrm{~S}$, each from mixtures with air by the tested aerogel sorbent, are shown in Figs. 6, 7 and 8 respectively. Excellent adsorption of NO and CO can be seen in Figs. 5 and 6. CO adsorption ranged from $90 \%$ to $98 \%$ and NO adsorption was nearly complete (i.e., $98-100 \%$ ). Adsorption of $\mathrm{H}_{2} \mathrm{~S}$, in Fig. 7, on the other hand, started at $90 \%$ then decreased with time to about $40 \%$ after about 105 minutes of contacting with the aerogel sorbent. The exact reason for this behavior is not known, but it is believed that the presence of water vapor from the activation step might have interfered with adsorption reaction between $\mathrm{H}_{2} \mathrm{~S}$ and $\mathrm{CaO}$ \& $\mathrm{MgO}$, which results in the release of water molecules, as shown in Table 1. Therefore, $\mathrm{H}_{2} \mathrm{~S}$ adsorption should be improved (a) at higher temperatures where water would be removed by drying, (b) with no activation of the aerogel by steam.

\section{CONCLUSIONS}

Based on the experimental results for mixed gas adsorption, it can be concluded that calcium and magnesium oxides containing aerogels can effectively adsorb polluting gases such as $\mathrm{SO}_{2}, \mathrm{NO}, \mathrm{CO}_{2}, \mathrm{CO}$ and $\mathrm{H}_{2} \mathrm{~S}$ from air or flue gas streams. Similarly, aerogels containing other metallic oxides capable of reacting with these gases should provide excellent adsorbent materials. Furthermore, aerogel sorbents can be engineered to different forms, sizes, and chemical compositions to be used as gas filters for removal of pollution gases from air in the different workplaces and indoor living spaces.

\section{AKNOWLEDGMENTS}

The authors are very grateful to Dept. of Materials Science and Engineering, Ohio State University, U.S.A. for their lab facilities during the preparation of the aerogel materials.

\section{REFERENCES}

1. Smith, P.V.,"Economics of Sorbent Injection for Coal Fired Boiler Acid Gas Control", in Processing and Utilization of High Sulfur Coals IV, P.R. Dugan, D.R. Quigley and Y.A. Attia (Eds.), Elsevier, Amestrdam, 1991, p. 791823.

2. Zhijiang, L., Xuyi, Z. and H. Xingyi, H', "Research on the Effect of Pore Size Distribution of Sulfur Sorbent on the Performance of Sulfur Capture", ibid, p. 731. 
3. Zhang, C., Xu, G. and Lian, X., "Criteria of Sulfur Capture Performance of Limestone", ibid, p. 723-729.

4. Beier, E., "Entschweflungsverfahren fur Kohlenge feuerte Kraftwerke", Gluckauf Forschungshefte, 42,1981, p. 38.

5. Richter, E., Knoblauch, K. And Juntgen, H., "Methods Using Activated Coke for the Removal of $\mathrm{SO}_{2}$ and $\mathrm{CO}_{2}$ from the Flue Gases of Firing Systems", in Processing and Utilization of High Sulfur Coals, Y.A. Attia (Ed.), Elsevier, Amsterdam, 1985, p. 563.

6. Brinker, C.J. and Scherer, G.W., "Sol-Gel Science, the Physics and Chemistry of Sol-Gel Science", Academic Press, New York, 1990, (881 p.).

7. Fricke, J. (Ed), "Aerogels", Springer-Verlag, Berlin Heidelberg, 1986, (205 p.).

8. a) Ahmed, M.S. and Attia, Y.A., "Sol-Gel Prepared Aerogels for Adsorption/Capture of Hazardous Gases", First International Conference on Application Commercialization of Sol Gel Processing, Saarbruken-Germany, October 10-13, 1993.

b) Attia, Y.A., " Capture of Greenhouse Gases by Novel Aerogel Sorbents Prepared by SolGel Technology ", Processing and Utilization of High-Sulfur Cools V, B.K. Parekh and J.G. Groppo (Eds.), Elsevier Science Publishers B.V., 1993, pp. 467-484. 


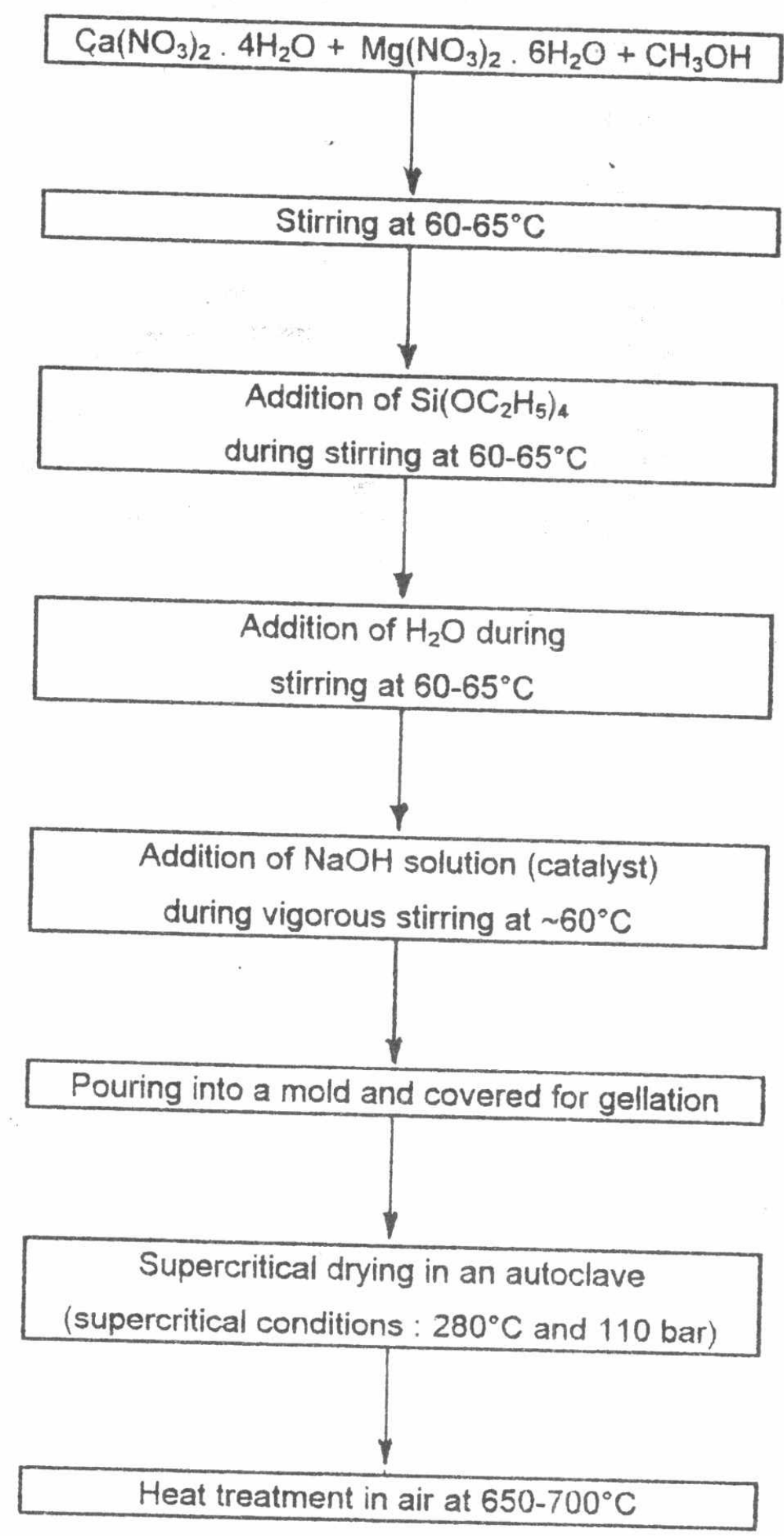

Fig. 2. Flowchart of the procedure and precursors used to prepare the aerogel sorbent in the present work. 


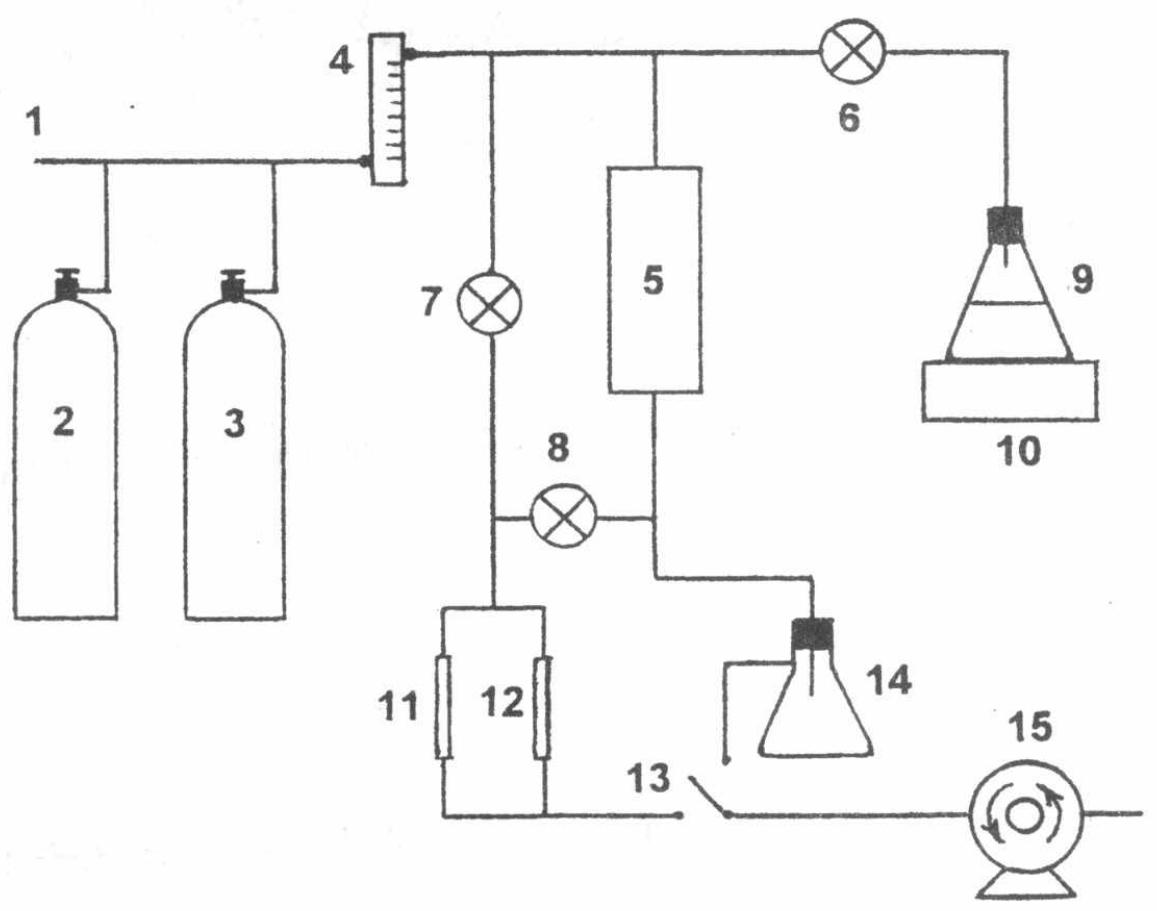

Fig. 3. Experimental setup for gas adsorption by the aerogel sorbent.

1. Inlet air

2 \& 3. Gas cylinders

4. Flowneter

5. Adsorption chamber containing aerogel sample

$6,7 \& 8$. Valves

9. Steam generator 10. Heater

11 \& 12. Drager Gas Detector Tubes (SKC Inc., PA, U.S.A.)
13. Switch
14. Gas trap
15. Pump. 

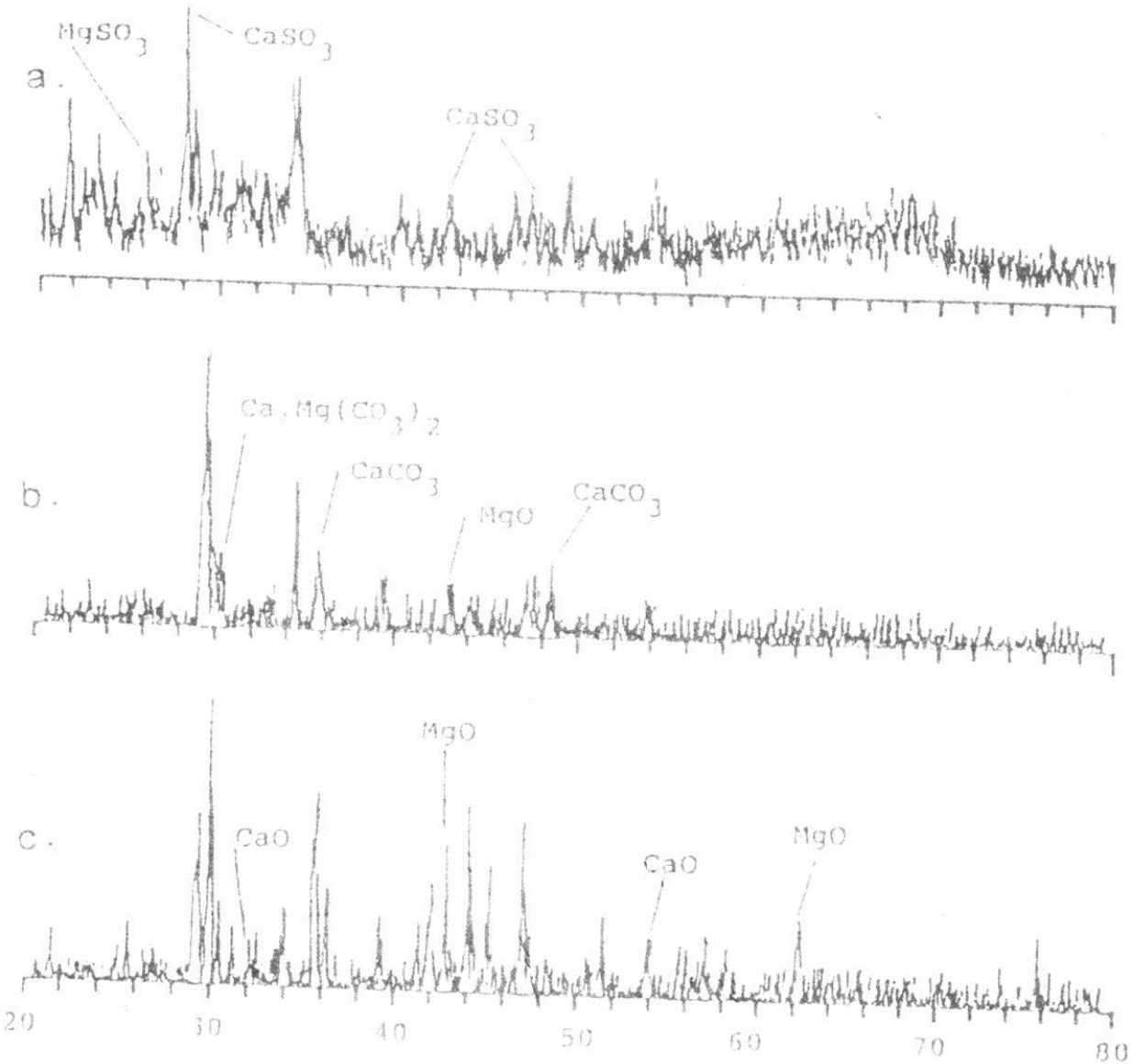

Fig. 4. X-ray diffraction spectograms of the aerogel sorbent before and after adsorbtion of $\mathrm{CO}_{2}$ and $\mathrm{SO}_{2}$ gases, [ 8 ].

(a) Aerogel after $\mathrm{SO}_{2}$ adsorption

(b) Aerogel after $\mathrm{CO}_{2}$ adsorption

(c) Fresh aerogel sample 


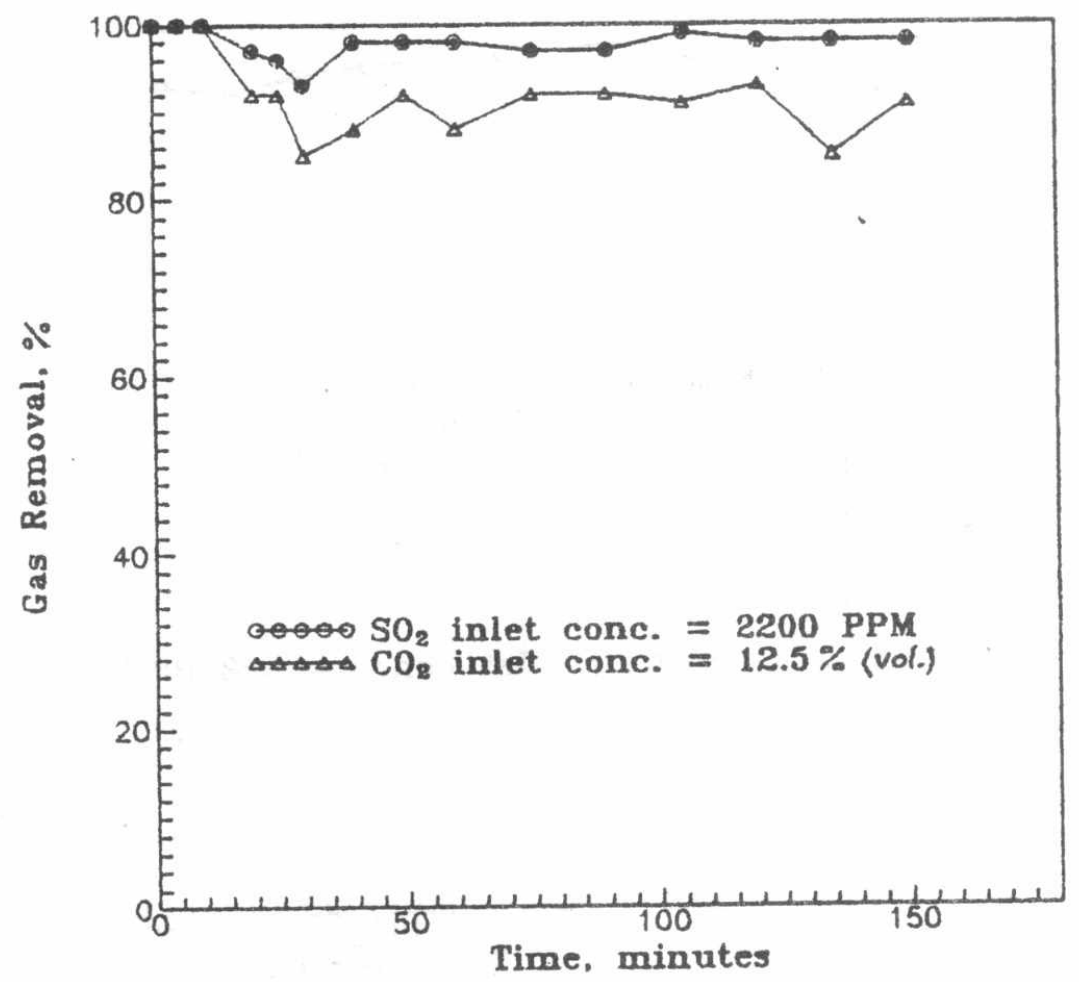

Fig. 5. Removal of $\mathrm{CO}_{2}$ and $\mathrm{SO}_{2}$ from air by the aerogel sorbent.

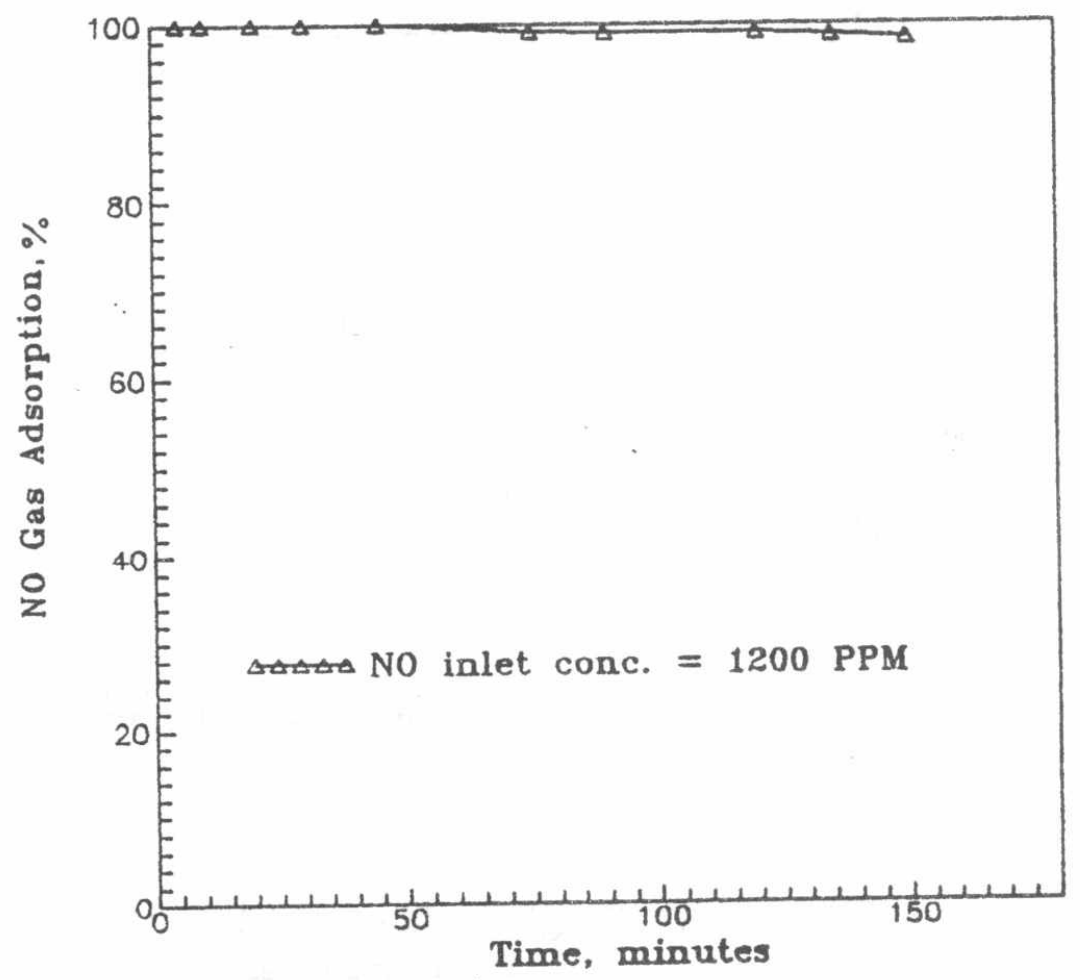

Fig. 6. Removal of NO from air by the aerogel sorbent. 


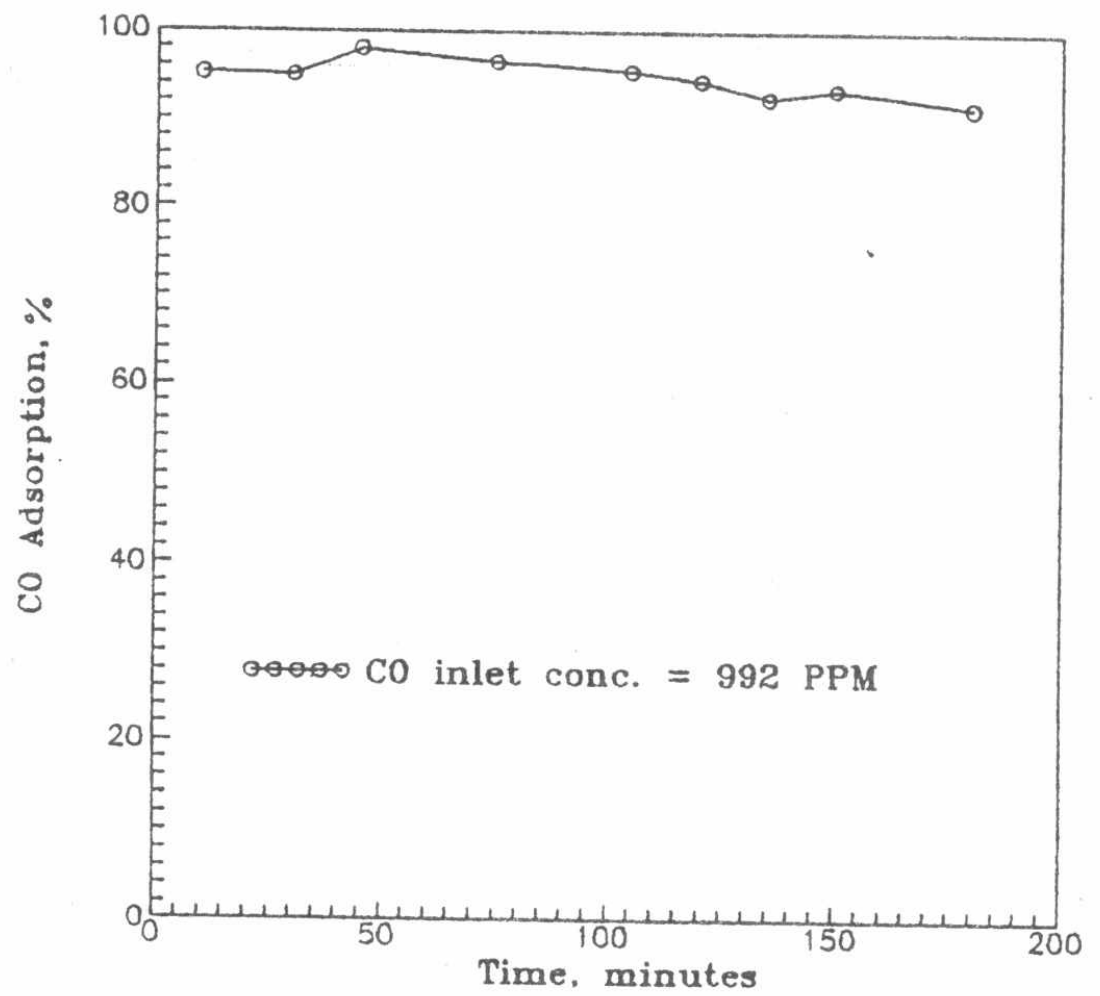

Fig. 7. Removal of $\mathrm{CO}$ from air by the aerogel sorbent.

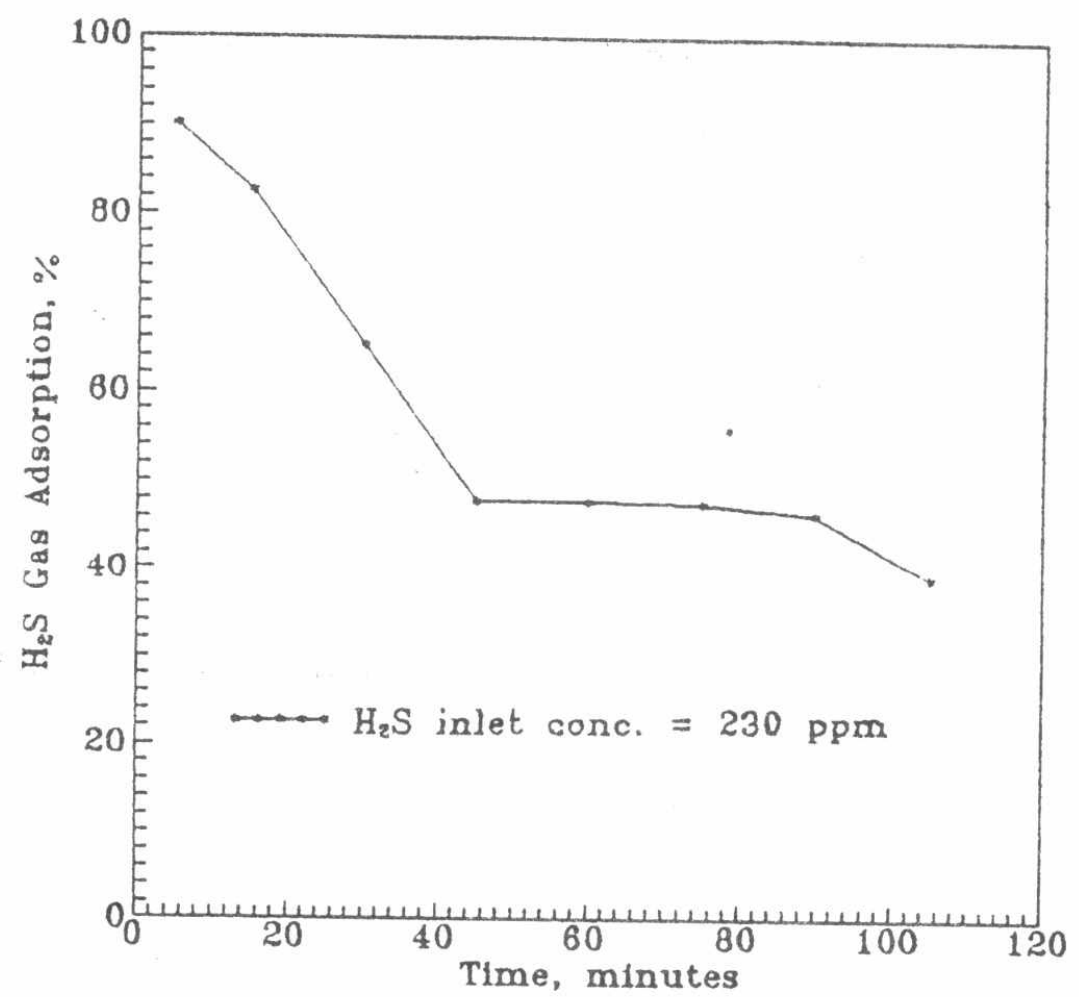

Fig. 8. Removal of $\mathrm{H}_{2} \mathrm{~S}$ from air by the aerogel sorbent. 
Table 1. Possible adsorption reactions between gases and the aerogel sorbent.

* Active sites on aerogels : $\mathrm{CaO} \& \mathrm{MgO}$

* Adsorption of $\mathrm{H}_{2} \mathrm{O}$ vapor (steain)

$\mathrm{CaO}+\mathrm{H}_{2} \mathrm{O}=\mathrm{Ca}(\mathrm{OH})_{2}$ (surface)

$\mathrm{MgO}+\mathrm{H}_{2} \mathrm{O}=\mathrm{Mg}(\mathrm{OH})_{2}$ (surface)

* Adsorption of $\mathrm{SO}_{2}$

$\mathrm{Ca}(\mathrm{OH})_{2}+\mathrm{SO}_{2}=\mathrm{CaSO}_{3}+\mathrm{H}_{2} \mathrm{O} ; \mathrm{CaSO}_{3}+1 / 2 \mathrm{O}_{2}=\mathrm{CaSO}_{4}$

$\mathrm{Mg}(\mathrm{OH})_{2}+\mathrm{SO}_{2}=\mathrm{MgSO}_{3}+\mathrm{H}_{2} \mathrm{O} ; \mathrm{MgSO}_{3}+\mathrm{I} / 2 \mathrm{O}_{2}=\mathrm{MgSO}_{4}$

* Adsorption of $\mathrm{CO}_{2}$

$\mathrm{Ca}(\mathrm{OH})_{2}+\mathrm{CO}_{2}=\mathrm{CaCO}_{3}+\mathrm{H}_{2} \mathrm{O}$

$\mathrm{Mg}(\mathrm{OH})_{2}+\mathrm{CO}_{2}=\mathrm{MgCO}_{3}+\mathrm{H}_{2} \mathrm{O}$

* Adsorption of $\mathrm{CO}$

$\mathrm{Ca}(\mathrm{OH})_{2}+\mathrm{CO}+1 / 2 \mathrm{O}_{2}=\mathrm{CaCO}_{3}+\mathrm{H}_{2} \mathrm{O}$

$\mathrm{Mg}(\mathrm{OH})_{2}+\mathrm{CO}+1 / 2 \mathrm{O}_{2}=\mathrm{MgCO}_{3}+\mathrm{H}_{2} \mathrm{O}$

* Adsorption of NO

$\mathrm{Ca}(\mathrm{OH})_{2}+2 \mathrm{NO}+3 / 2 \mathrm{O}_{2}=\mathrm{Ca}\left(\mathrm{NO}_{3}\right)_{2}+\mathrm{H}_{2} \mathrm{O}$

$\mathrm{Mg}(\mathrm{OH})_{2}+2 \mathrm{NO}+3 / 2 \mathrm{O}_{2}=\mathrm{Mg}\left(\mathrm{NO}_{3}\right)_{2}+\mathrm{H}_{2} \mathrm{O}$

* Adsorption of $\mathrm{H}_{2} \mathrm{~S}$ (in absence of steam activation)

$\mathrm{CaO}+\mathrm{H}_{2} \mathrm{~S}=\mathrm{CaS}+\mathrm{H}_{2} \mathrm{O}$

$\mathrm{MgO}+\mathrm{H}_{2} \mathrm{~S}=\mathrm{MgS}+\mathrm{H}_{2} \mathrm{O}$ 